\title{
Evaluating Properties of Carbon-free Nano NiCoFe-LDHs with Molybdate as Oxygen Evolution Catalysts and Their Applications in Rechargeable Air Electrodes
}

\author{
Qiang Liu, Fang Zhou, Yuying Bai and Weikang $\mathrm{Hu}^{*}$ \\ Key Laboratory of Advanced Catalytic Materials (Ministry of Education) \\ College of Chemistry and Life Science \\ Zhejiang Normal University, Zhejiang, Jinhua 321004, PR China
}

Email address: weikang.hu@zjnu.edu.cn

Tel: $+86-15397114713$

*Corresponding author 
Table S1. The chemical composition was analyzed by ICP and EDX, and compared with the feed composition.

\begin{tabular}{|l|l|l|}
\hline Feed composition ratio & ICP element analysis & EDX element analysis \\
\hline $\mathrm{NiCo}_{1.8} \mathrm{Fe}_{0.2}$ & $\mathrm{NiCo}_{2.54} \mathrm{Fe}_{0.49}$ & $\mathrm{NiCo}_{2.51} \mathrm{Fe}_{0.37}$ \\
\hline $\mathrm{NiCo}_{1.5} \mathrm{Fe}_{0.5}$ & $\mathrm{NiCo}_{2.62} \mathrm{Fe}_{0.65}$ & $\mathrm{NiCo}_{2.88} \mathrm{Fe}_{0.77}$ \\
\hline $\mathrm{NiCo}_{1.0} \mathrm{Fe}_{1.0}$ & $\mathrm{NiCo}_{2.30} \mathrm{Fe}_{1.51}$ & $\mathrm{NiCo}_{2.80} \mathrm{Fe}_{2.82}$ \\
\hline $\mathrm{NiCo}_{1.5} \mathrm{Fe}_{0.5} @ 7.9 \mathrm{at} \%$ & $\mathrm{NiCo}_{2.40} \mathrm{Fe}_{0.19} @ 10.6 \mathrm{at} \%$ & $\mathrm{NiCo}_{2.45} \mathrm{Fe}_{0.65} @ 3.82 \mathrm{at} \%$ \\
$\mathrm{MoO}_{4}{ }^{2-}$ & $\mathrm{MoO}_{4}{ }^{2-}$ & $\mathrm{MoO}_{4}{ }^{2-}$ \\
\hline $\mathrm{NiCo}_{1.5} \mathrm{Fe}_{0.5} @ 14.7 \mathrm{at} \%$ & $\mathrm{NiCo}_{2.60} \mathrm{Fe}_{0.15} @ 15.6 \mathrm{at} \%$ & $\mathrm{NiCo}_{2.78} \mathrm{Fe}_{0.85} @ 4.70 \mathrm{at} \%$ \\
$\mathrm{MoO}_{4}{ }^{2-}$ & $\mathrm{MoO}_{4}{ }^{2-}$ & $\mathrm{MoO}_{4}{ }^{2-}$ \\
\hline $\mathrm{NiCo}_{1.5} \mathrm{Fe}_{0.5} @ 20.6 \mathrm{at} \%$ & $\mathrm{NiCo}_{2.56} \mathrm{Fe}_{0.36} @ 17.0 \mathrm{at} \%$ & $\mathrm{NiCo}_{2.82} \mathrm{Fe}_{0.68} @ 13.6 \mathrm{at} \%$ \\
$\mathrm{MoO}_{4}{ }^{2-}$ & $\mathrm{MoO}_{4}{ }^{2-}$ & $\mathrm{MoO}_{4}{ }^{2-}$ \\
\hline $\mathrm{NiCo}_{1.5} \mathrm{Fe}_{0.5} @ 25.7 \mathrm{at} \%$ & $\mathrm{NiCo}_{3.30} \mathrm{Fe}_{0.30} @ 19.4 \mathrm{at} \%$ & $\mathrm{NiCo}_{2.96} \mathrm{Fe}_{1.13} @ 17.6 \mathrm{at} \%$ \\
$\mathrm{MoO}_{4}{ }^{2-}$ & $\mathrm{MoO}_{4}{ }^{2-}$ & $\mathrm{MoO}_{4}{ }^{2-}$ \\
\hline
\end{tabular}

Table S2. Comparison of the electrochemical parameters of $\mathrm{NiCo}_{1.5} \mathrm{Fe}_{0.5}-\mathrm{LDHs}$ with 14.7 at $\% \mathrm{MoO}_{4}{ }^{2-}$ with literature's electrocatalysts.

\begin{tabular}{|c|c|c|c|c|}
\hline Prepared catalysts & $\begin{array}{l}\text { Overpotential at } \\
10 \mathrm{~mA} \mathrm{~cm}-2(\mathrm{mV})\end{array}$ & Tafel slope $\left(\mathrm{mV} \operatorname{dec}^{-1}\right)$ & Medium & Reference \\
\hline $\begin{array}{l}\mathrm{NiCo}_{1.5} \mathrm{Fe}_{0.5} \text {-LDHs } \\
\text { (a) } 14.7 \text { at\% } \mathrm{MoO}_{4}{ }^{2-}\end{array}$ & 239 & 43 & $1 \mathrm{M} \mathrm{KOH}$ & This work \\
\hline NiCo-LDHs & 367 & 40 & $1 \mathrm{M} \mathrm{KOH}$ & {$[16]$} \\
\hline NiCoFe-LDHs & 288 & 92 & $1 \mathrm{M} \mathrm{KOH}$ & {$[21]$} \\
\hline $\mathrm{Ni}_{2} \mathrm{Co}_{1} \mathrm{Fe}_{1}-\mathrm{LDHs}$ & 240.4 & 38.4 & $1 \mathrm{M} \mathrm{KOH}$ & {$[23]$} \\
\hline NiFe-LDHs & 280 & 40 & $1 \mathrm{M} \mathrm{KOH}$ & [31] \\
\hline CNO@NiCo-LDHs & 290 & 31 & $1 \mathrm{M} \mathrm{KOH}$ & {$[40]$} \\
\hline
\end{tabular}


Table S3. The electrochemical performances of various samples.

\begin{tabular}{|c|c|c|c|c|}
\hline Samples & $\begin{array}{l}\text { Overpotential at } \\
10 \mathrm{~mA} \mathrm{~cm}^{-2}(\mathrm{mV})\end{array}$ & $\begin{array}{l}\text { Tafel slope } \\
\left(\mathbf{m V} \operatorname{dec}^{-1}\right)\end{array}$ & $\begin{array}{c}\text { BET } \\
\left(\mathbf{m}^{2} \mathbf{g}^{-1}\right)\end{array}$ & $\begin{array}{c}\text { ECSA } \\
\left(\mathrm{mF} \mathrm{cm}^{-2}\right)\end{array}$ \\
\hline $\mathrm{NiCo}_{1.8} \mathrm{Fe}_{0.2}-\mathrm{LDHs}$ & 256 & 41.8 & 27 & 1.95 \\
\hline $\mathrm{NiCo}_{1.5} \mathrm{Fe}_{0.5}$-LDHs & 256 & 45.4 & 83 & 1.56 \\
\hline $\mathrm{NiCo}_{1.0} \mathrm{Fe}_{1.0}-\mathrm{LDHs}$ & 264 & 44.4 & 154 & 1.02 \\
\hline $\begin{array}{l}\mathrm{NiCo}_{1.5} \mathrm{Fe}_{0.5^{-}} \\
\text {LDHs@7.9at\% } \mathrm{MoO}_{4}^{2-}\end{array}$ & 245 & 43.4 & 174 & 1.68 \\
\hline $\begin{array}{l}\mathrm{NiCo}_{1.5} \mathrm{Fe}_{0.5^{-}} \\
\text {LDHs@14.7at\% } \mathrm{MoO}_{4}^{2-}\end{array}$ & 239 & 43.1 & 117 & 1.65 \\
\hline $\begin{array}{l}\mathrm{NiCo}_{1.5} \mathrm{Fe}_{0.5^{-}} \\
\mathrm{LDHs} @ 20.6 \mathrm{at} \% \mathrm{MoO}_{4}^{2-}\end{array}$ & 252 & 53.9 & 52 & 1.43 \\
\hline $\begin{array}{l}\mathrm{NiCo}_{1.5} \mathrm{Fe}_{0.5^{-}} \\
\mathrm{LDHs} @ 25.7 \mathrm{at} \% \mathrm{MoO}_{4}^{2-}\end{array}$ & 263 & 61.4 & 36 & 1.25 \\
\hline
\end{tabular}

In order to further understand the function of molybdate anions, $0.4 \mathrm{~g}$ sodium molybdate solution was added to $20 \mathrm{ml}$ ethanol solutions of $\mathrm{Co}\left(\mathrm{NO}_{3}\right)_{2} \cdot 6 \mathrm{H}_{2} \mathrm{O}(0.73 \mathrm{~g})$, $\mathrm{Ni}\left(\mathrm{NO}_{3}\right)_{2} \cdot 6 \mathrm{H}_{2} \mathrm{O}(0.73 \mathrm{~g})$ and $\mathrm{Fe}\left(\mathrm{NO}_{3}\right)_{3} \cdot 9 \mathrm{H}_{2} \mathrm{O}(0.5 \mathrm{~g})$, respectively. The results show that differently colored insoluble products can be formed under approximately neutral conditions (Figs.S1a-c). After their precipitates are centrifuged, rinsed and dried, XRD examination (Fig.S2a(I)) shows that a mixed phase composed of $\mathrm{CoMoO}_{4}$ and $\alpha-\mathrm{Co}(\mathrm{OH})_{2}$ is observed in the $\mathrm{Co}^{2+}$ solution. When a $0.6 \mathrm{M}$ ammonia solution further drops to the above solution until $\mathrm{pH} \approx 9$, however, the phase transformation to a pure $\alpha$-phase Co-LDH from the mixed phase occurs and the solution color also changes to navy blue, as shown in Fig. S1d. The occurrence of phase transition is because the cobalt hydroxide has a small value of solubility product constants $\left(\mathrm{K}_{\mathrm{sp}}=10^{-15}\right)$. XRD structure analyses also confirm 
the phase transition from $\mathrm{CoMoO}_{4}$ into $\mathrm{Co}(\mathrm{OH})_{2}$ when the ammonia solution is added to increase the $\mathrm{pH}$ value until $\mathrm{pH} \approx 9$, as shown in Fig. $\mathrm{S} 2 \mathrm{~b}(\mathrm{I})$. For the reaction of $\mathrm{Ni}^{2+}$ ions with $\mathrm{MoO}_{4}{ }^{2-}$, a similar phase transition with the formation of a bluish green $\mathrm{Ni}(\mathrm{OH})_{2}$ from a light green turbid suspension of $\mathrm{NiMoO}_{4}$ takes place as well after the $0.6 \mathrm{M}$ ammonia solution is added until $\mathrm{pH} \approx 9$, as shown in Figs. S3c and S3f. For the ferric (III) nitrate solution, the $\mathrm{Fe}^{3+}$ ions mainly form the ferrihydrite species $(\mathrm{FeO}(\mathrm{O}, \mathrm{OH}))$ under $\mathrm{pH}=5-7$ and then the ferrihydrite phase changes to a mixed phase of goethite $(\alpha-\mathrm{FeOOH})$ and hematite $\left(\alpha-\mathrm{Fe}_{2} \mathrm{O}_{3} \cdot \mathrm{xH}_{2} \mathrm{O}\right)$ when the $0.6 \mathrm{M}$ ammonia is added into the solution until $\mathrm{pH} \approx 8$ 9. ${ }^{1,2}$ The molybdate plays the role to prevent the crystal growth of ferrihydrite, goethite and hematite phases due to its adsorption effect on these phases. ${ }^{2}$ XRD examinations also confirm the characteristic peaks of amorphous phase, as shown in Figs.S2a(II) and 2b(II), showing the broad diffraction peaks at $2 \theta \approx 25^{\circ}$ and $35^{\circ}$, respectively. It is noticed that the crystal growth at the (003) plane of $\alpha-\mathrm{Ni}(\mathrm{OH})_{2}$ is also suppressed under presence of sodium molybdate, as shown in Figs.S2b(III). The phenomenon of the suppressed (003) plane and poor crystallinity of LDHs with additions of sodium molybdate have been observed in Fig.2b. These results are related to the greater static attraction of bivalent $\mathrm{MoO}_{4}{ }^{2-}$ with cationic charges on the plane of LDHs than the monovalent $\mathrm{NO}_{3}{ }^{-}$although the ion radius of $\mathrm{MoO}_{4}{ }^{2-}(2.31 \AA)$ is larger than that of $\mathrm{NO}_{3}{ }^{-}(2.0 \AA) .^{3}$ In order to further verify the existence of molybdate anion, SEM energy-dispersive X-ray (EDX) element analyses and Raman spectra were performance on these catalysts. The results reveal that the Mo content gradually increases with increasing the additions of $\mathrm{MoO}_{4}{ }^{2-}$, as shown in Table S1 and Figs.S3-4. 

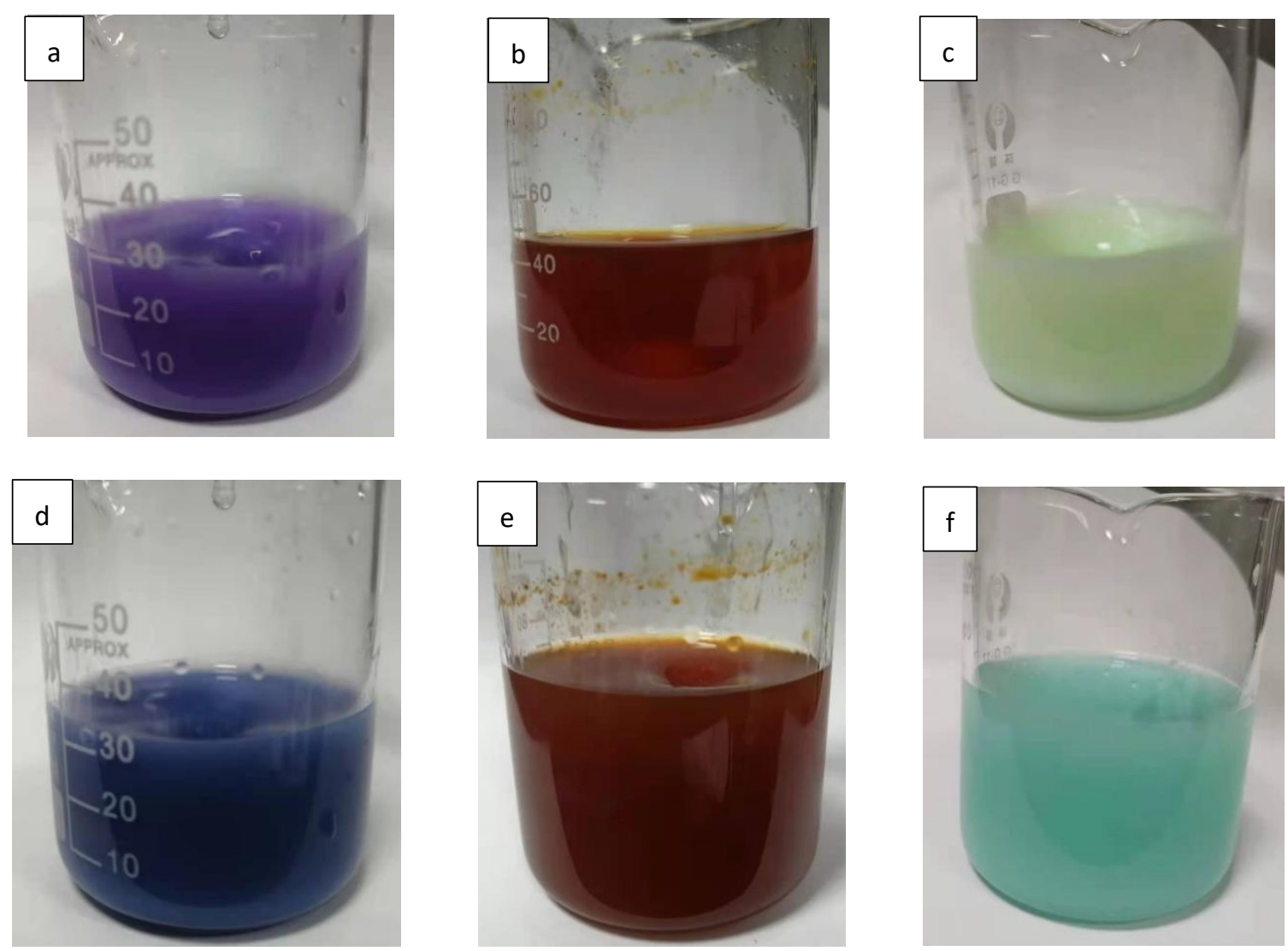

Fig.S1. (a) violet precipitate with a mixed phase of $\mathrm{CoMoO}_{4}$ and $\mathrm{Co}(\mathrm{OH})_{2}$ was obtained when the $\mathrm{Co}\left(\mathrm{NO}_{3}\right)_{2}$ solution was added dropwise with the $\mathrm{Na}_{2} \mathrm{MoO}_{4}$ solution; (b) a light brown ferrihydrite was formed when the $\mathrm{Fe}\left(\mathrm{NO}_{3}\right)_{3}$ solution was added dropwise with the $\mathrm{Na}_{2} \mathrm{MoO}_{4}$ solution; (c) a light green turbid suspension of $\mathrm{NiMoO}_{4}$ was obtained when the $\mathrm{Ni}\left(\mathrm{NO}_{3}\right)_{2}$ solution was added dropwise with the $\mathrm{Na}_{2} \mathrm{MoO}_{4}$ solution; (d) a navy blue $\mathrm{Co}(\mathrm{OH})_{2}$ precipitate was obtained after $0.6 \mathrm{M} \mathrm{NH}_{4} \mathrm{OH}$ was added in the (a) solution until $\mathrm{pH} \approx 9$; (e) a brown $\mathrm{FeOOH}$ after $0.6 \mathrm{M} \mathrm{NH} \mathrm{NH}_{4}$ was added in the (b) solution until $\mathrm{pH} \approx 9$; (f) a bluish green $\mathrm{Ni}(\mathrm{OH})_{2}$ after $0.6 \mathrm{M} \mathrm{NH}_{4} \mathrm{OH}$ was added in the (c) solution until $\mathrm{pH} \approx 9$. 

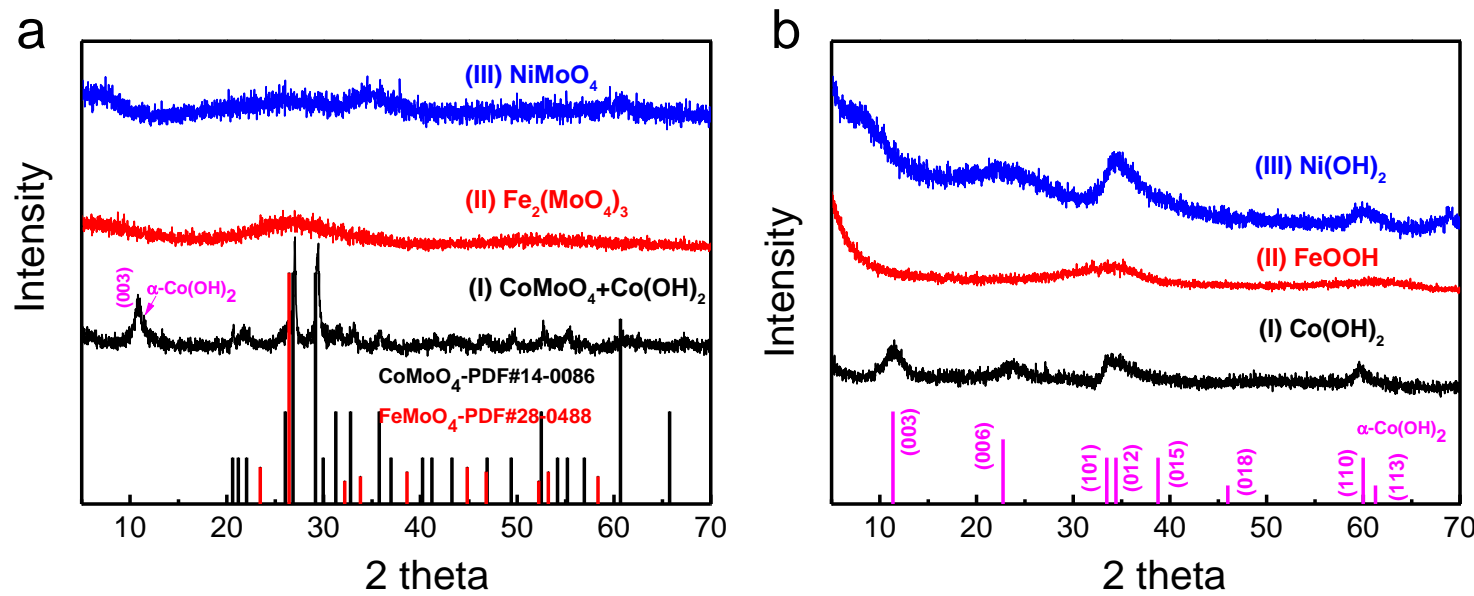

Fig.S2. (a) XRD patterns of (I) $\mathrm{CoMoO}_{4} \cdot \mathrm{xH}_{2} \mathrm{O}+\alpha-\mathrm{Co}(\mathrm{OH})_{2}$, (II) Ferrihydrite, (III) $\mathrm{NiMoO}_{4}$; (b) XRD patterns of (I) $\alpha-\mathrm{Co}(\mathrm{OH})_{2}$, (II) $\alpha-\mathrm{FeOOH}$ and $\alpha-\mathrm{Fe}_{2} \mathrm{O}_{3} \cdot \mathrm{xH}_{2} \mathrm{O}$, (III) $\alpha-\mathrm{Ni}(\mathrm{OH})_{2}$.

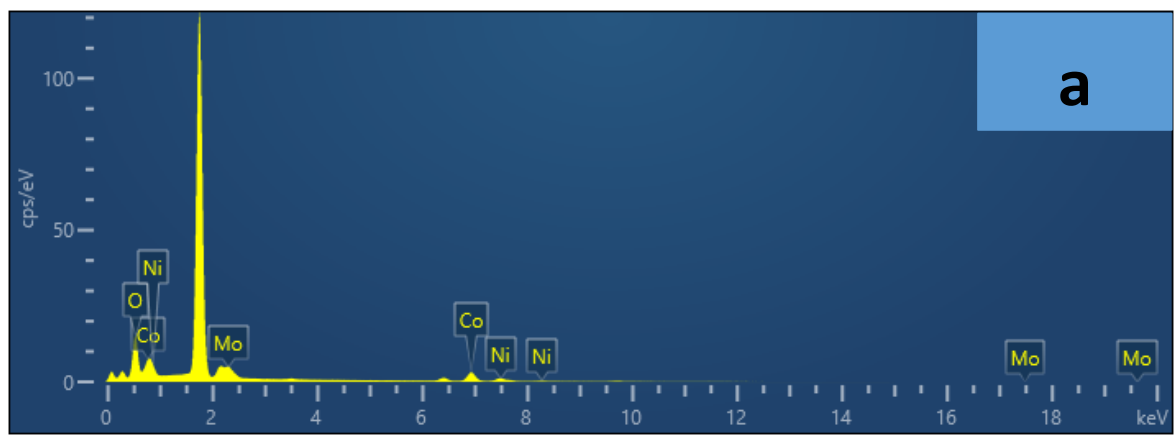

\begin{tabular}{|c|c|c|c|c|}
\hline \multicolumn{5}{|c|}{$\mathrm{NiCo}_{1.5} \mathrm{Fe}_{0.5}$ with additions of 7.9at\% $\mathrm{MoO}_{4}{ }^{2-}$} \\
\hline The element & Line type & $\begin{array}{c}\text { Percentage by } \\
\text { weight }\end{array}$ & Wt \% Sigma & Atomic percentage \\
\hline $\mathrm{O}$ & $\mathrm{K}$ & 33.68 & 0.21 & 65.50 \\
\hline $\mathrm{Co}$ & $\mathrm{K}$ & 37.31 & 0.25 & 19.70 \\
\hline $\mathrm{Ni}$ & $\mathrm{K}$ & 15.16 & 0.25 & 8.04 \\
\hline $\mathrm{Fe}$ & $\mathrm{K}$ & 9.75 & 0.16 & 5.43 \\
\hline $\mathrm{Mo}$ & $\mathrm{L}$ & 4.09 & 0.23 & 1.33 \\
\hline The total & & 100.00 & & 100.00 \\
\hline
\end{tabular}

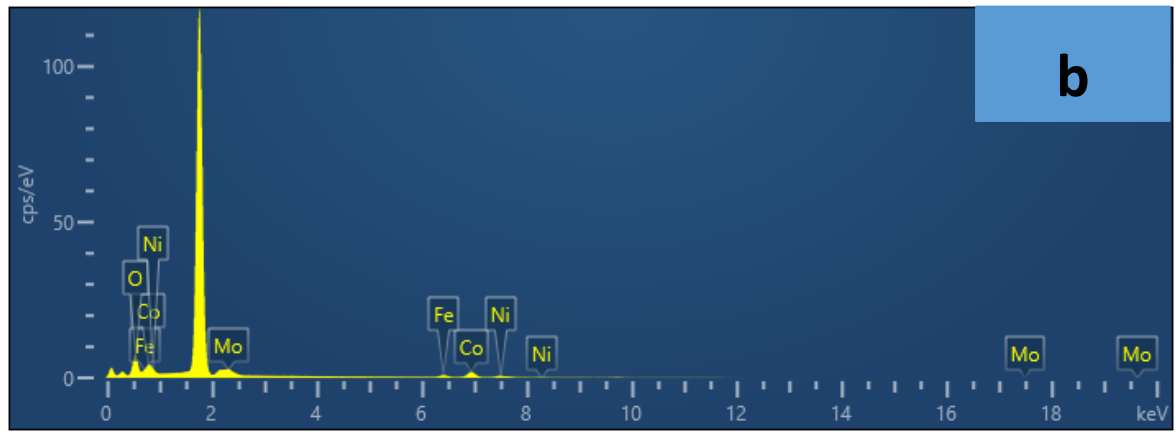




\begin{tabular}{|c|c|c|c|c|}
\hline \multicolumn{5}{|c|}{$\mathrm{NiCo}_{1.5} \mathrm{Fe}_{0.5}$ with additions of $14.7 \mathrm{at} \% \mathrm{MoO}_{4}{ }^{2-}$} \\
\hline The element & Line type & $\begin{array}{c}\text { Percentage by } \\
\text { weight }\end{array}$ & Wt \% Sigma & Atomic percentage \\
\hline O & $\mathrm{K}$ & 31.05 & 0.29 & 62.84 \\
\hline $\mathrm{Co}$ & $\mathrm{K}$ & 38.74 & 0.37 & 21.28 \\
\hline $\mathrm{Ni}$ & $\mathrm{K}$ & 13.84 & 0.37 & 7.63 \\
\hline $\mathrm{Fe}$ & $\mathrm{K}$ & 11.21 & 0.26 & 6.50 \\
\hline $\mathrm{Mo}$ & $\mathrm{L}$ & 5.16 & 0.32 & 1.74 \\
\hline The total & & 100.00 & & 100.00 \\
\hline
\end{tabular}

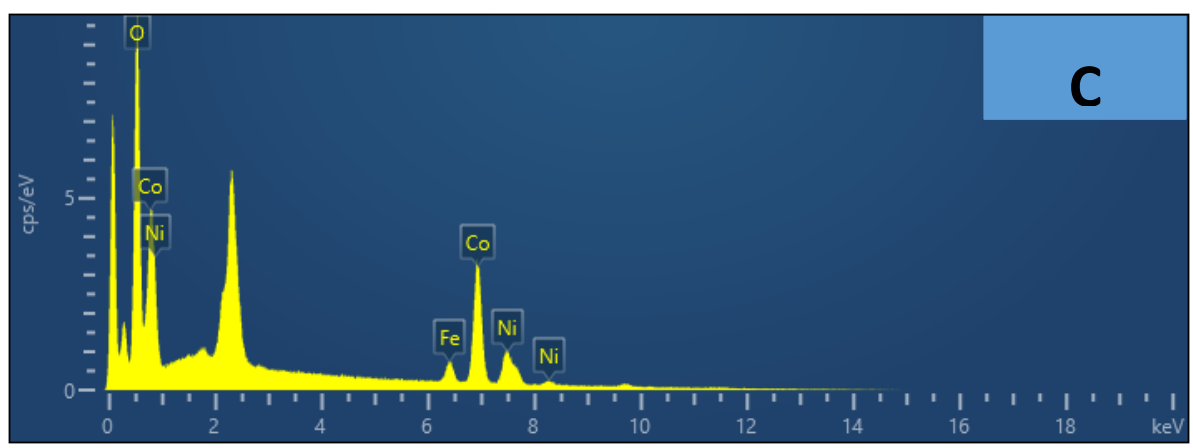

\begin{tabular}{|c|c|c|c|c|}
\hline \multicolumn{5}{|c|}{$\mathrm{NiCo}_{1.5} \mathrm{Fe}_{0.5}$ with $20.6 \mathrm{at}_{\%} \mathrm{MoO}_{4}{ }^{2-}$} \\
\hline The element & Line type & $\begin{array}{c}\text { Percentage by } \\
\text { weight }\end{array}$ & Wt \% Sigma & Atomic percentage \\
\hline $\mathrm{O}$ & $\mathrm{K}$ & 27.94 & 0.20 & 60.70 \\
\hline $\mathrm{Co}$ & $\mathrm{K}$ & 36.08 & 0.27 & 21.25 \\
\hline $\mathrm{Fe}$ & $\mathrm{K}$ & 8.29 & 0.14 & 5.14 \\
\hline $\mathrm{Ni}$ & $\mathrm{K}$ & 12.83 & 0.25 & 7.54 \\
\hline $\mathrm{Mo}$ & $\mathrm{L}$ & 14.86 & 0.22 & 5.38 \\
\hline The total & & 100.00 & & 100.00 \\
\hline
\end{tabular}

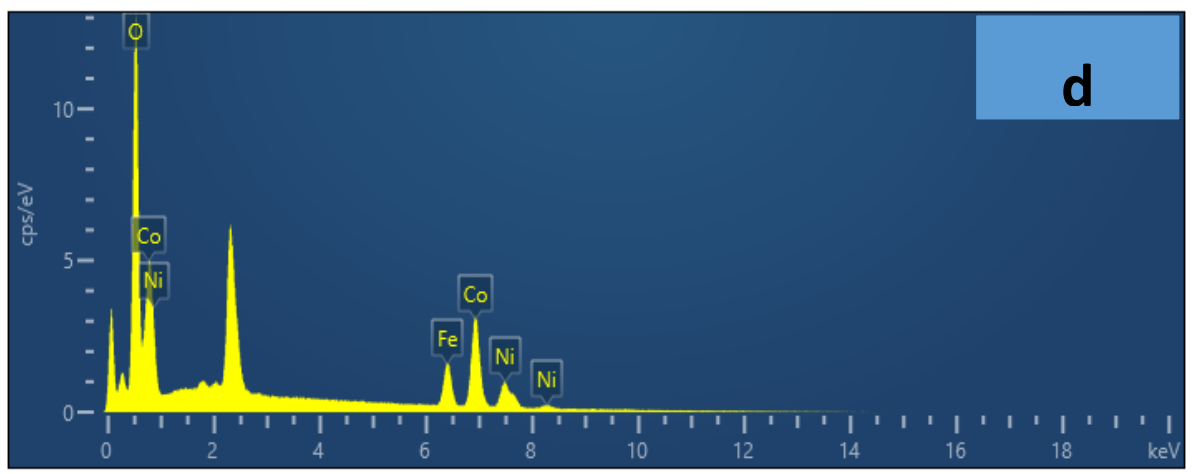

\begin{tabular}{|c|c|c|c|c|}
\hline \multicolumn{5}{|c|}{$\mathrm{NiCo}_{1.5} \mathrm{Fe}_{0.5}$ with additions of $25.7 \% \mathrm{MoO}_{4}{ }^{2-}$} \\
\hline The element & Line type & $\begin{array}{c}\text { Percentage by } \\
\text { weight }\end{array}$ & Wt \% Sigma & Atomic percentage \\
\hline O & $\mathrm{K}$ & 31.21 & 0.18 & 64.78 \\
\hline Co & $\mathrm{K}$ & 29.94 & 0.22 & 16.87 \\
\hline
\end{tabular}




\begin{tabular}{|c|c|c|c|c|}
\hline $\mathrm{Ni}$ & $\mathrm{K}$ & 10.08 & 0.20 & 5.70 \\
\hline $\mathrm{Fe}$ & $\mathrm{K}$ & 10.84 & 0.15 & 6.44 \\
\hline $\mathrm{Mo}$ & $\mathrm{L}$ & 17.93 & 0.17 & 6.21 \\
\hline The total & & 100.00 & & 100.00 \\
\hline
\end{tabular}

Fig.S3. EDX spectra and elemental analyses on surface of $\mathrm{NiCo}_{1.5} \mathrm{Fe}_{0.5}$ with additions of (a) $7.9 \mathrm{at} \% \mathrm{MoO}_{4}{ }^{2-}$; (b) $14.7 \mathrm{at} \% \mathrm{MoO}_{4}{ }^{2-}$; (c) $20.6 \% \mathrm{MoO}_{4}{ }^{2-}$ and (d) $25.7 \% \mathrm{MoO}_{4}{ }^{2-}$.

Fig.S3 shows the EDX spectra, which reveal that these LDHs with additions of $\mathrm{MoO}_{4}{ }^{2-}$ anions present the Mo element and its content gradually increases with increasing the additions of $\mathrm{MoO}_{4}{ }^{2-}$ anions.

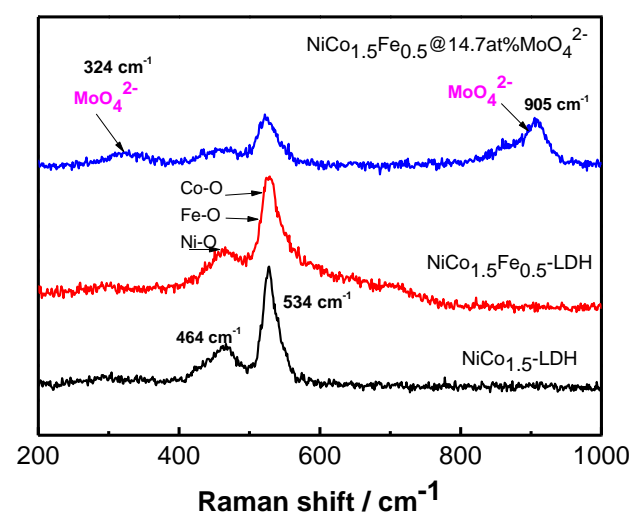

Fig. S4. Raman spectra of the $\mathrm{NiCo}_{1.5} \mathrm{Fe}_{0.5}-\mathrm{LDH}$, the $\mathrm{NiCo}_{1.5} \mathrm{Fe}_{0.5}-\mathrm{LDH} @ 14.7 \mathrm{at} \% \mathrm{MoO}_{4}{ }^{2-}$ and the $\mathrm{NiCo}_{1.5}-\mathrm{LDH}$.

Fig. S4 shows Raman spectra of the $\mathrm{NiCo}_{1.5} \mathrm{Fe}_{0.5}$ and $\mathrm{NiCo}_{1.5} \mathrm{Fe}_{0.5} @ 14.7 \mathrm{at} \% \mathrm{MoO}_{4}^{2-}$ catalysts, compared to the $\mathrm{NiCo}_{1.5}$-LDH sample. Both $\mathrm{NiCo}_{1.5} \mathrm{Fe}_{0.5}$ and $\mathrm{NiCo}_{1.5} \mathrm{Fe}_{0.5} @ 14.7$ at\% $\mathrm{MoO}_{4}{ }^{2-}$ samples exhibit bands at $464 \mathrm{~cm}^{-1}$ and $534 \mathrm{~cm}^{-1}$, which are assigned to the stretching vibration of $\mathrm{Ni}-\mathrm{O}, \mathrm{Co}-\mathrm{O}$ and $\mathrm{Fe}-\mathrm{O}$. For the sample with the addition of $14.7 \mathrm{at} \% \mathrm{MoO}_{4}{ }^{2-}$, the feature modes of $\mathrm{MoO}_{4}{ }^{2-}$ at $324 \mathrm{~cm}^{-1}$ (bending modes) and $905 \mathrm{~cm}^{-1}$ (symmetric stretching modes) appear, indicating the presence of $\mathrm{MoO}_{4}{ }^{2-}$ anions. 

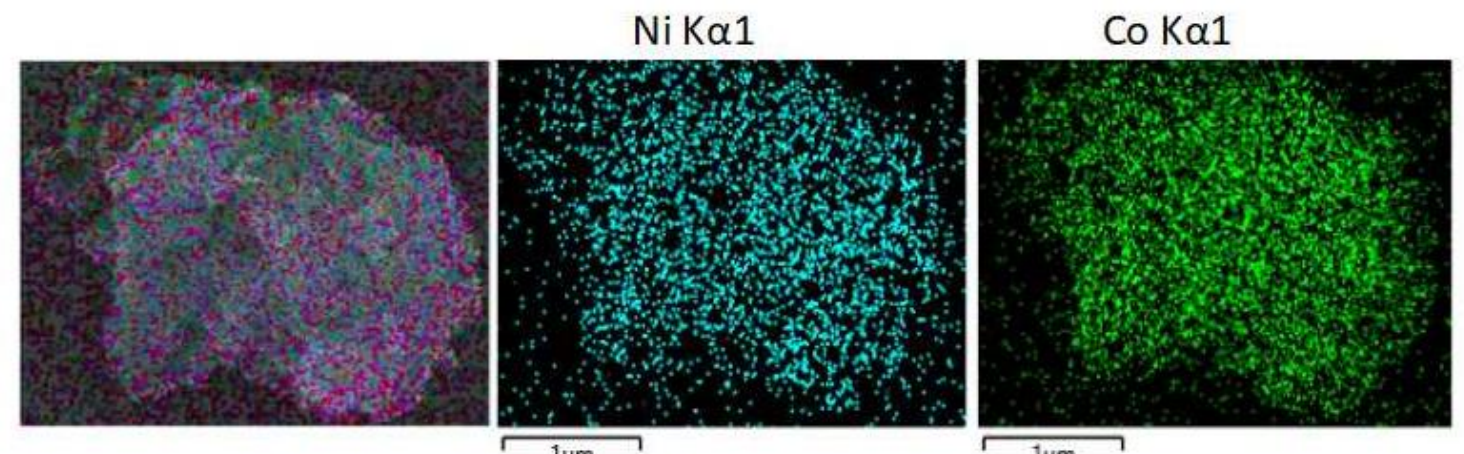

$\mathrm{Fe} \mathrm{K} \alpha 1$

$\mathrm{O} K \alpha 1$
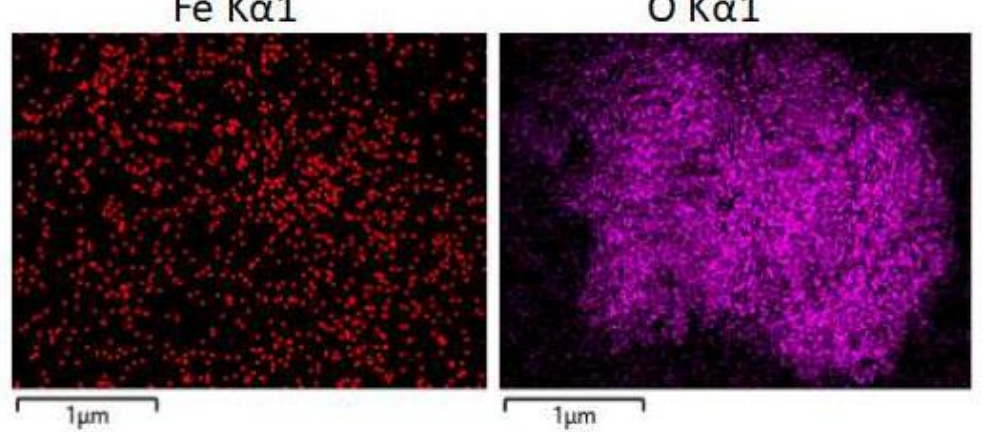

$1 \mu \mathrm{m}$

Fig.S5a. Elemental mappings of $\mathrm{Ni}, \mathrm{Co}, \mathrm{Fe}$ and $\mathrm{O}$ of the $\mathrm{NiCo}_{1.5} \mathrm{Fe}_{0.5}-\mathrm{LDH}$ sample.
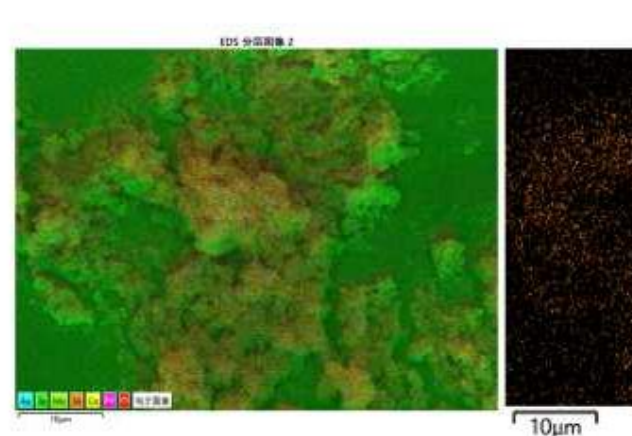

Ni Ka1

Co $K \alpha 1$
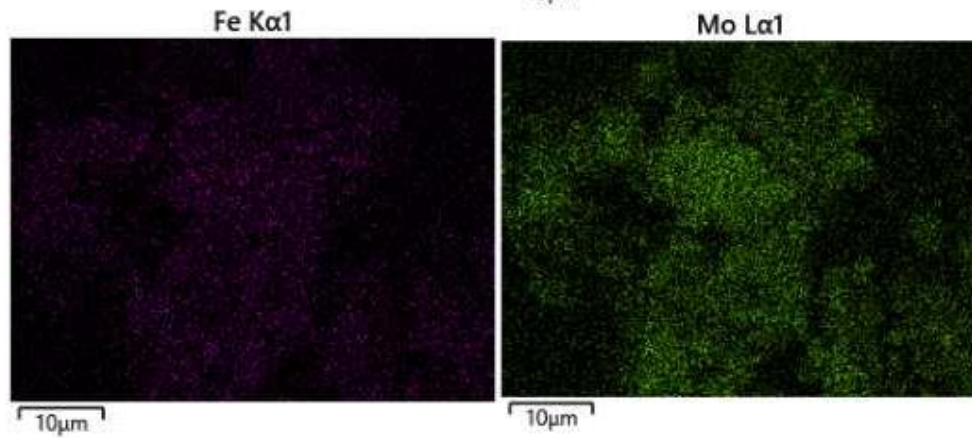

O Ka1

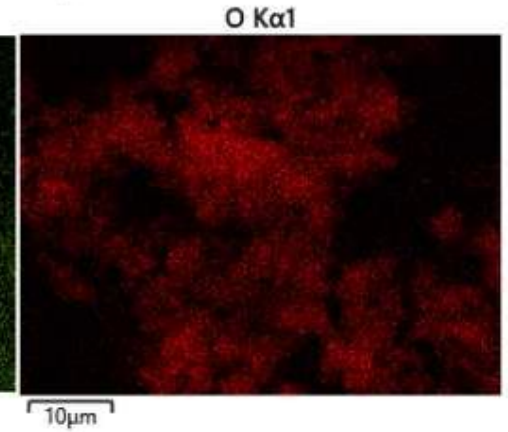

Fig.S5b. Elemental mappings of Ni, Co, Fe, Mo and $\mathrm{O}$ of the $\mathrm{NiCo}_{1.5} \mathrm{Fe}_{0.5}-\mathrm{LDH} @ 14.7$ at\% $\mathrm{MoO}_{4}{ }^{2-}$ sample. 

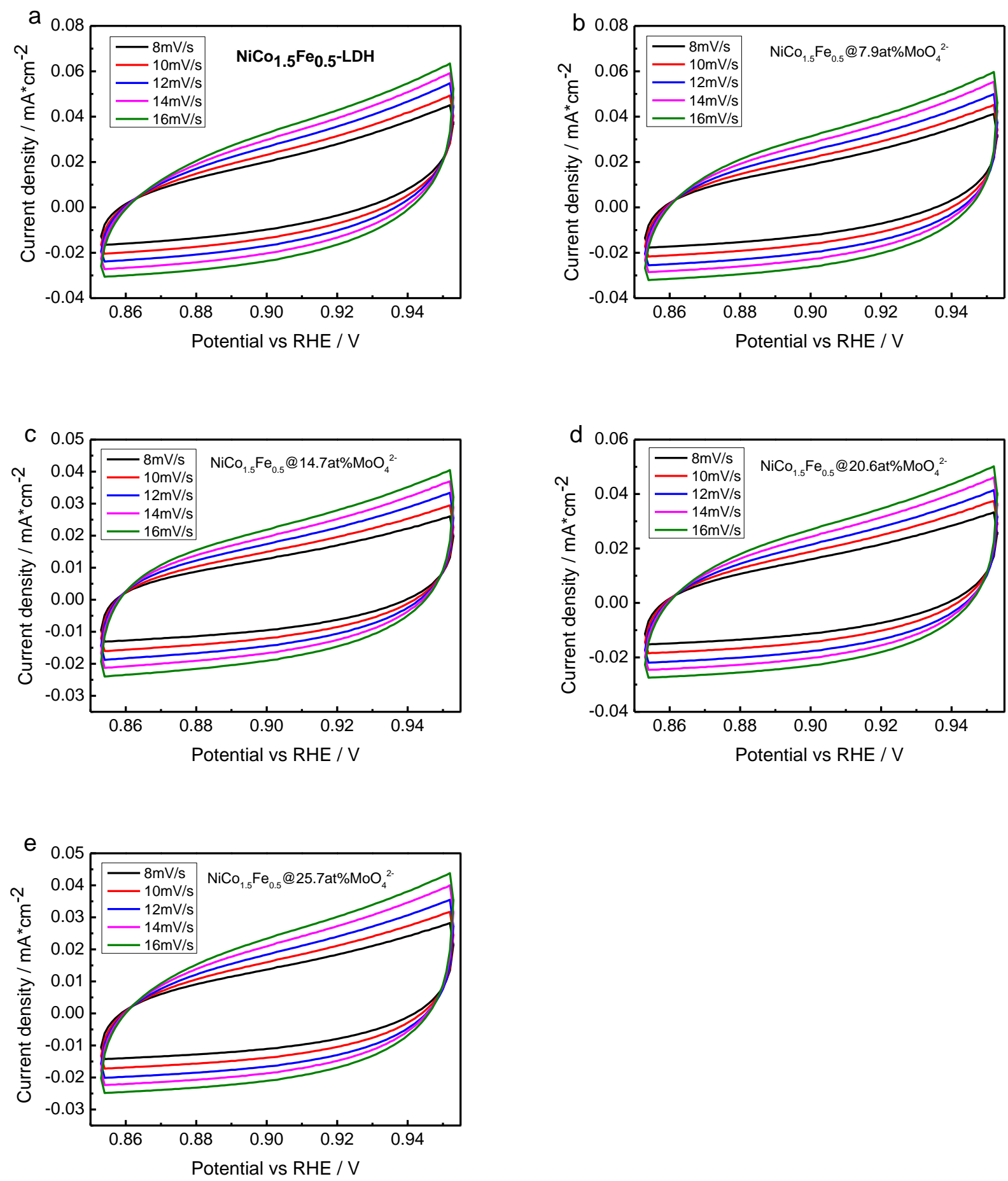

Fig.S6. A series of CV curves for double-layer capacitance measurements at orderly scanning rates from 8 to $16 \mathrm{mV} \mathrm{s}^{-1}$ in a non-Faradaic region of (a) $\mathrm{NiCo}_{1.5} \mathrm{Fe}_{0.5}$; (b) $\mathrm{NiCo}_{1.5} \mathrm{Fe}_{0.5} @ 7.9 \mathrm{at} \% \mathrm{MoO}_{4}{ }^{2-}$; (c) $\mathrm{NiCo}_{1.5} \mathrm{Fe}_{0.5} @ 14.7 \mathrm{at} \% \mathrm{MoO}_{4}{ }^{2-}$; (d) $\mathrm{NiCo}_{1.5} \mathrm{Fe}_{0.5} @ 20.6 \mathrm{at} \%$ $\mathrm{MoO}_{4}{ }^{2-} ;(\mathrm{e}) \mathrm{NiCo}_{1.5} \mathrm{Fe}_{0.5} @ 25.7 \mathrm{at} \% \mathrm{MoO}_{4}{ }^{2-}$. 


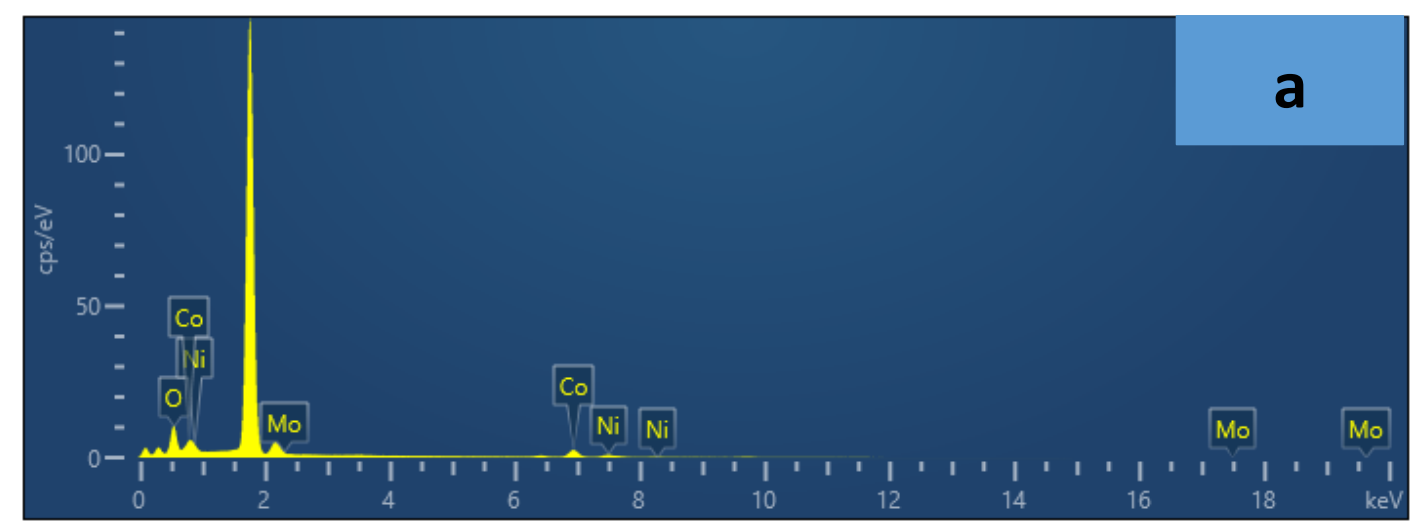

\begin{tabular}{|c|c|c|c|c|}
\hline \multicolumn{5}{|c|}{ NiCo ${ }_{1.8} \mathrm{Fe}_{0.2}$ sample } \\
\hline The element & Line type & $\begin{array}{c}\text { Percentage by } \\
\text { weight }\end{array}$ & Wt \% Sigma & Atomic percentage \\
\hline O & $\mathrm{K}$ & 31.14 & 0.25 & 62.35 \\
\hline Co & $\mathrm{K}$ & 44.86 & 0.34 & 24.38 \\
\hline $\mathrm{Ni}$ & $\mathrm{K}$ & 17.74 & 0.35 & 9.68 \\
\hline Fe & $\mathrm{K}$ & 6.26 & 0.22 & 3.59 \\
\hline Mo & $\mathrm{L}$ & 0.00 & 0.29 & 0.00 \\
\hline The total & & 100.00 & & 100.00 \\
\hline
\end{tabular}

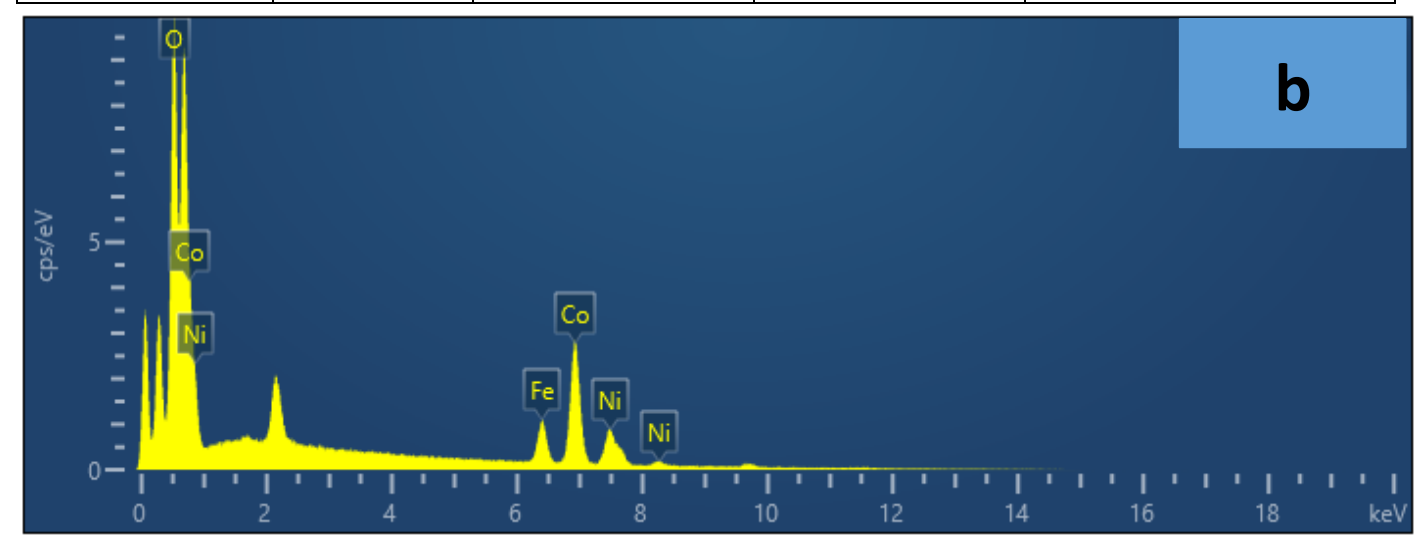

\begin{tabular}{|c|c|c|c|c|}
\hline \multicolumn{5}{|c|}{$\mathrm{NiCo}_{1.5} \mathrm{Fe}_{0.5}$ sample } \\
\hline The element & Line type & $\begin{array}{c}\text { Percentage by } \\
\text { weight }\end{array}$ & Wt \% Sigma & Atomic percentage \\
\hline $\mathrm{O}$ & $\mathrm{K}$ & 26.04 & 0.22 & 56.23 \\
\hline $\mathrm{Co}$ & $\mathrm{K}$ & 46.14 & 0.31 & 27.05 \\
\hline $\mathrm{Ni}$ & $\mathrm{K}$ & 16.30 & 0.31 & 9.59 \\
\hline $\mathrm{Fe}$ & $\mathrm{K}$ & 11.53 & 0.20 & 7.13 \\
\hline The total & & 100.00 & & 100.00 \\
\hline
\end{tabular}




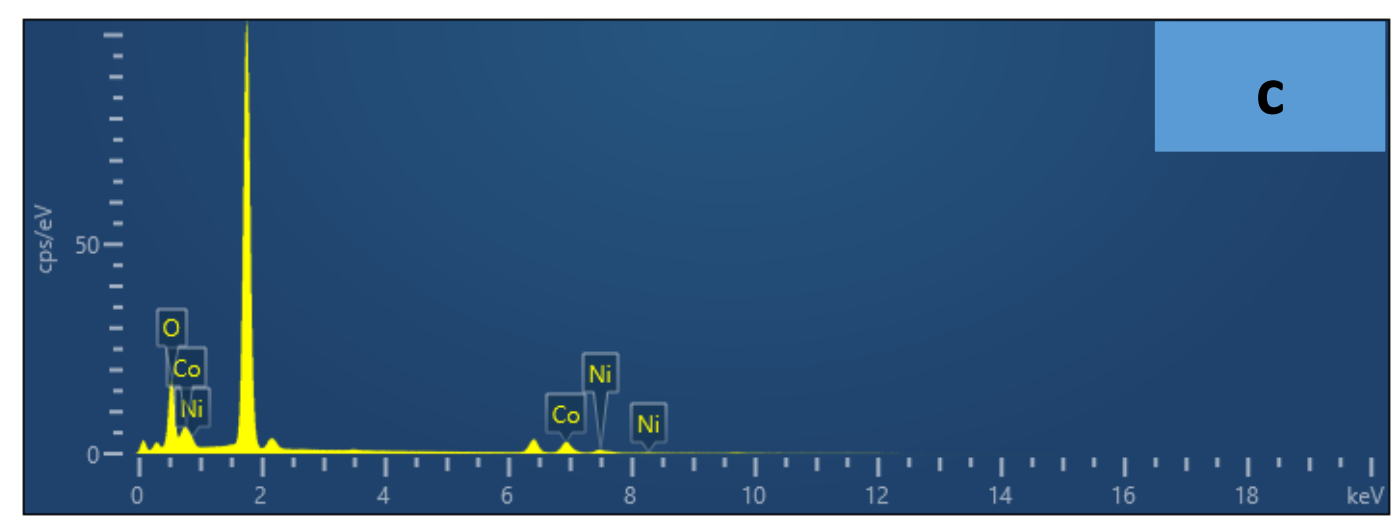

\begin{tabular}{|c|c|c|c|c|}
\hline \multicolumn{5}{|c|}{$\mathrm{NiCo}_{1.0} \mathrm{Fe}_{1.0}$ sample } \\
\hline The element & Line type & $\begin{array}{c}\text { Percentage by } \\
\text { weight }\end{array}$ & Wt \% Sigma & Atomic percentage \\
\hline $\mathrm{O}$ & $\mathrm{K}$ & 31.75 & 0.21 & 62.60 \\
\hline $\mathrm{Co}$ & $\mathrm{K}$ & 29.52 & 0.27 & 15.80 \\
\hline $\mathrm{Ni}$ & $\mathrm{K}$ & 10.47 & 0.27 & 5.63 \\
\hline $\mathrm{Fe}$ & $\mathrm{K}$ & 28.26 & 0.24 & 15.97 \\
\hline The total & & 100.00 & & 100.00 \\
\hline
\end{tabular}

Fig. S7. SEM-EDX spectra and elemental analyses on surface of (a) $\mathrm{NiCo}_{1.8} \mathrm{Fe}_{0.2}$ sample; (b) $\mathrm{NiCo}_{1.5} \mathrm{Fe}_{0.5}$ sample and (c) $\mathrm{NiCo}_{1.0} \mathrm{Fe}_{1.0}$ sample.
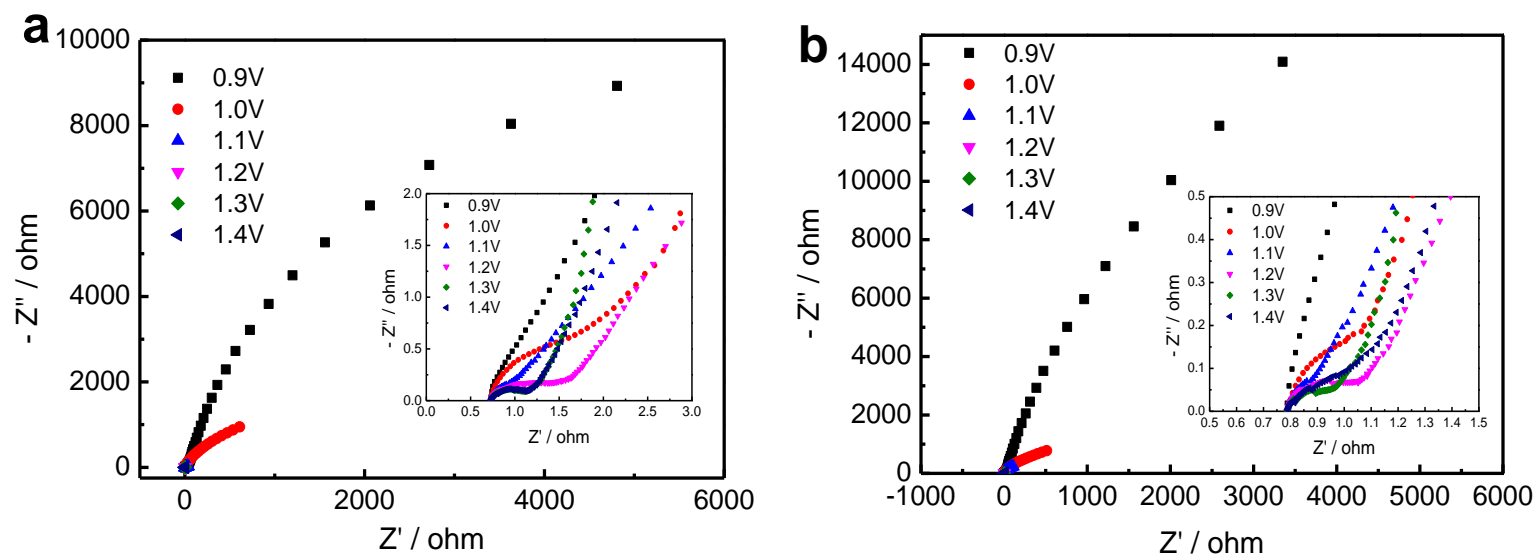

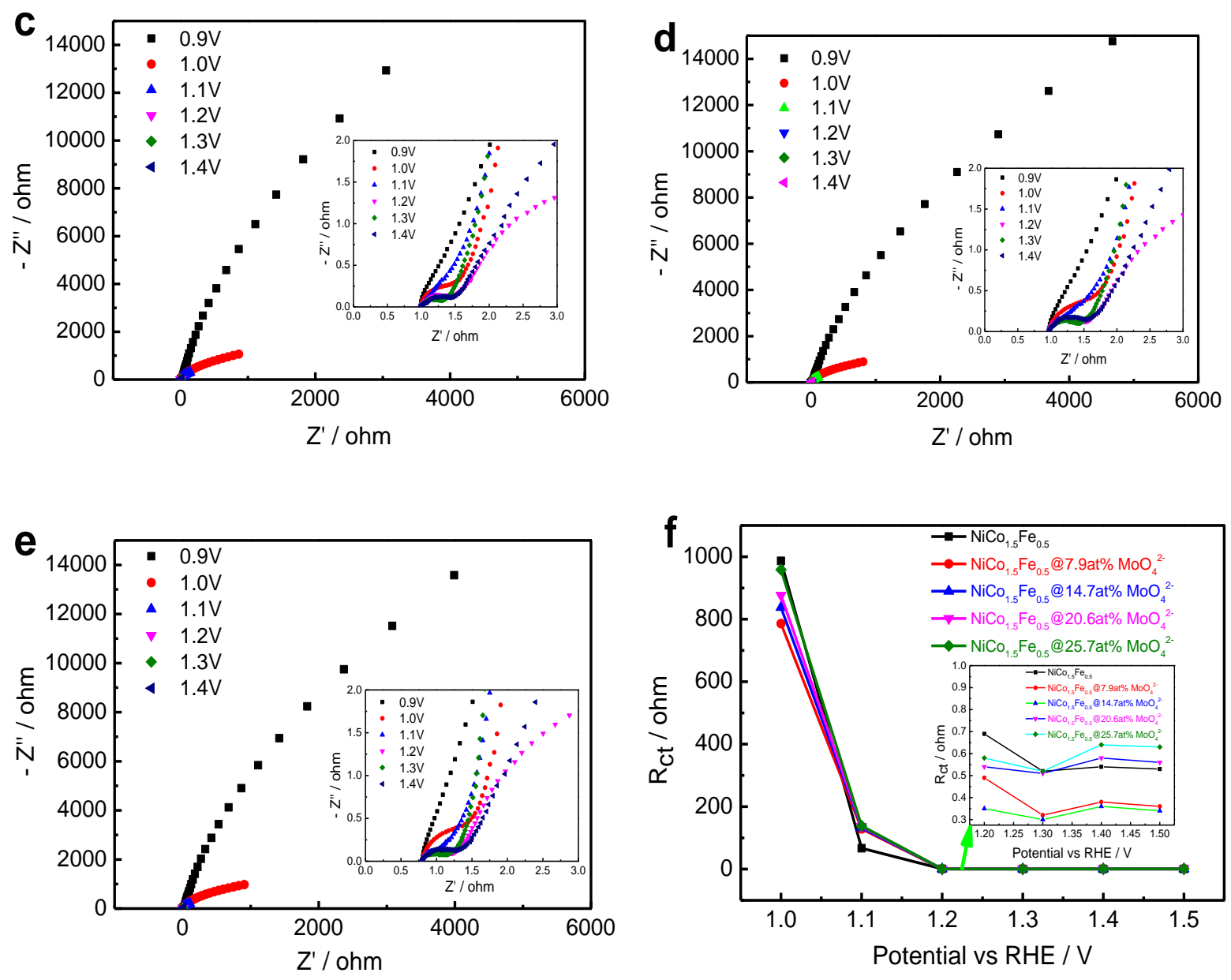

Figure S8. The Nyquist plots of (a) $\mathrm{NiCo}_{1.5} \mathrm{Fe}_{0.5}$, (b) $\mathrm{NiCo}_{1.5} \mathrm{Fe}_{0.5} @ 7.9$ at\% $\mathrm{MoO}_{4}^{2-}$, (c) $\mathrm{NiCo}_{1.5} \mathrm{Fe}_{0.5} @ 14.7 \mathrm{at} \% \mathrm{MoO}_{4}{ }^{2-}$, (d) $\mathrm{NiCo}_{1.5} \mathrm{Fe}_{0.5} @ 20.6 \mathrm{at} \% \mathrm{MoO}_{4}{ }^{2-}$, (e) $\mathrm{NiCo}_{1.5} \mathrm{Fe}_{0.5} @ 25.7 \mathrm{at} \%$ $\mathrm{MoO}_{4}{ }^{2-}$ acquired at $0.9,1.0,1.1,1.2,1.3$, and $1.4 \mathrm{~V}$ vs RHE, respectively in $1.0 \mathrm{M} \mathrm{KOH}$, and (f) the change curve of $R_{c t}$ value at different potentials.

By testing EIS at different potentials, ${ }^{4}$ we found that a large impedance at OCP $(0.9 \mathrm{~V}$ vs RHE), indicating no charge transfer between materials. At the same time, with the increase of potential, the impedance decreased obviously, indicating that there is partial charge transfer in the electrode when the potential is $1.0 \mathrm{~V}$ and $1.1 \mathrm{~V}$. When the potential reaches about $1.3 \mathrm{~V}$, the mass transfer resistance is very small and dose not change much, indicting that the charge transfer inside the material reaches the maximum. In addition, when the potential reaches $1.4 \mathrm{~V}$, the external resistance and internal resistance increase slowly, which is duo to the evolution of oxygen, resulting in an increase of resistance of the solution and catalysts. 

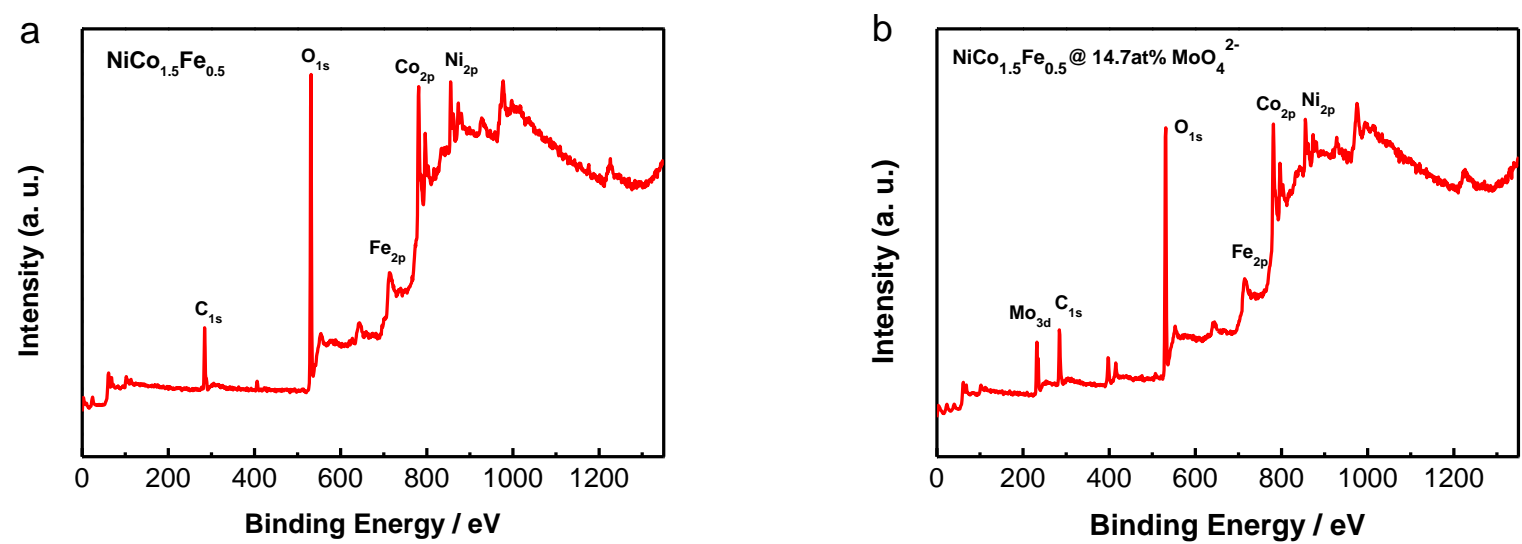

Fig.S9. XPS full survey spectra of (a) the pristine $\mathrm{NiCo}_{1.5} \mathrm{Fe}_{0.5}$ and (b) the $\mathrm{NiCo}_{1.5} \mathrm{Fe}_{0.5} @$ $14.7 \mathrm{at} \% \mathrm{MoO}_{4}^{2}$ samples.
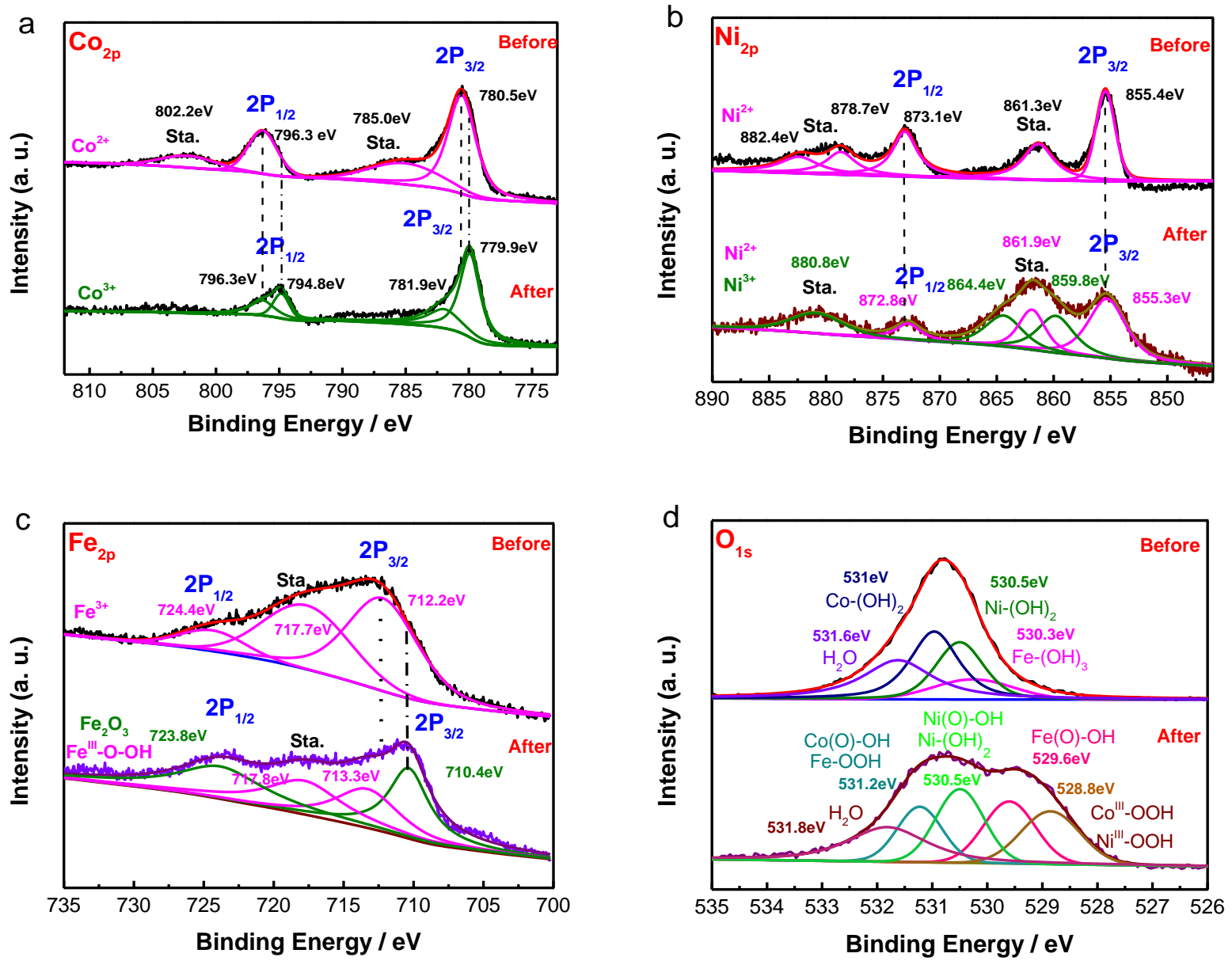

Fig.S10. XPS comparison of the $\mathrm{NiCo}_{1.5} \mathrm{Fe}_{0.5}$-LDHs before and after OER polarization for (a) Co2p spectrum, (b) Ni2p spectrum (c) Fe2p and (d) O1s spectra, respectively. 
For the $\mathrm{NiCo}_{1.5} \mathrm{Fe}_{0.5}$-LDH sample, the $\mathrm{Co} 2 \mathrm{p}$ spectrum contains two spin-orbit splitting Co2 $\mathrm{p}_{1 / 2}$ and $\mathrm{Co} 2 \mathrm{p}_{3 / 2}$ at $796.3 \mathrm{eV}$ and $780.5 \mathrm{eV}$ accompanied with their satellite peaks before electrolysis, which are assigned to the characteristic peaks of cobalt hydroxide phase with a $\mathrm{Co}^{2+}$ oxidation state. ${ }^{5,6}$ After electrolysis, the spin-orbit splitting $\mathrm{Co} 2 \mathrm{p}_{3 / 2}$ peak is deconvoluted to two peaks at $779.9 \mathrm{eV}$ and $781.9 \mathrm{eV}$, and the $\mathrm{Co} 2 \mathrm{p}_{1 / 2}$ at 794.8eV and 796.3eV (Fig.S10a), respectively, indicating the co-existence of $\mathrm{Co}^{3+}$ and $\mathrm{Co}^{2+}$. In addition, the $\mathrm{Co} 2 \mathrm{p}_{3 / 2}$ and $\mathrm{Co} 2 \mathrm{p}_{1 / 2}$ peaks shift to the lower binding energy with the difference of $14.9 \mathrm{eV}$, which is less than the difference of $15.8 \mathrm{eV}$ before electrolysis. After OER polarization, the shakeup satellite peaks at 785 and $802.2 \mathrm{eV}$ are absent in the Co2p spectrum, as shown in Fig.S10a. The difference indicates the existence of a $\mathrm{Co}^{3+}$ oxidation state after electrolysis. ${ }^{5,7}$ For the $\mathrm{Ni}_{2 p}$ spectrum after anodic polarization (Fig.S10b), the $\mathrm{Ni} 2 \mathrm{p}_{3 / 2}$ can be deconvoluted to two peaks with a $\mathrm{Ni}^{3+}$ oxidation state. The $\mathrm{Fe} 2 \mathrm{p}_{3 / 2}$ peak also shifts after polarization (Fig.S10c). More persuasively, two intense separated peaks at bonding energies of $530.8 \mathrm{eV}$ and $529.4 \mathrm{eV}$ in the high-resolution $\mathrm{O} 1 \mathrm{~s}$ spectrum (Fig.S10d) are clearly observed after OER polarization, compared with only one main peak at bonding energy of $530.8 \mathrm{eV}$ before polarization, indicating that the surface of the LDH sample is covered with trivalent metal (oxy)hydroxides of $\mathrm{CoOOH}, \mathrm{NiOOH}$ and $\mathrm{FeOOH}^{8}$ species after polarization.
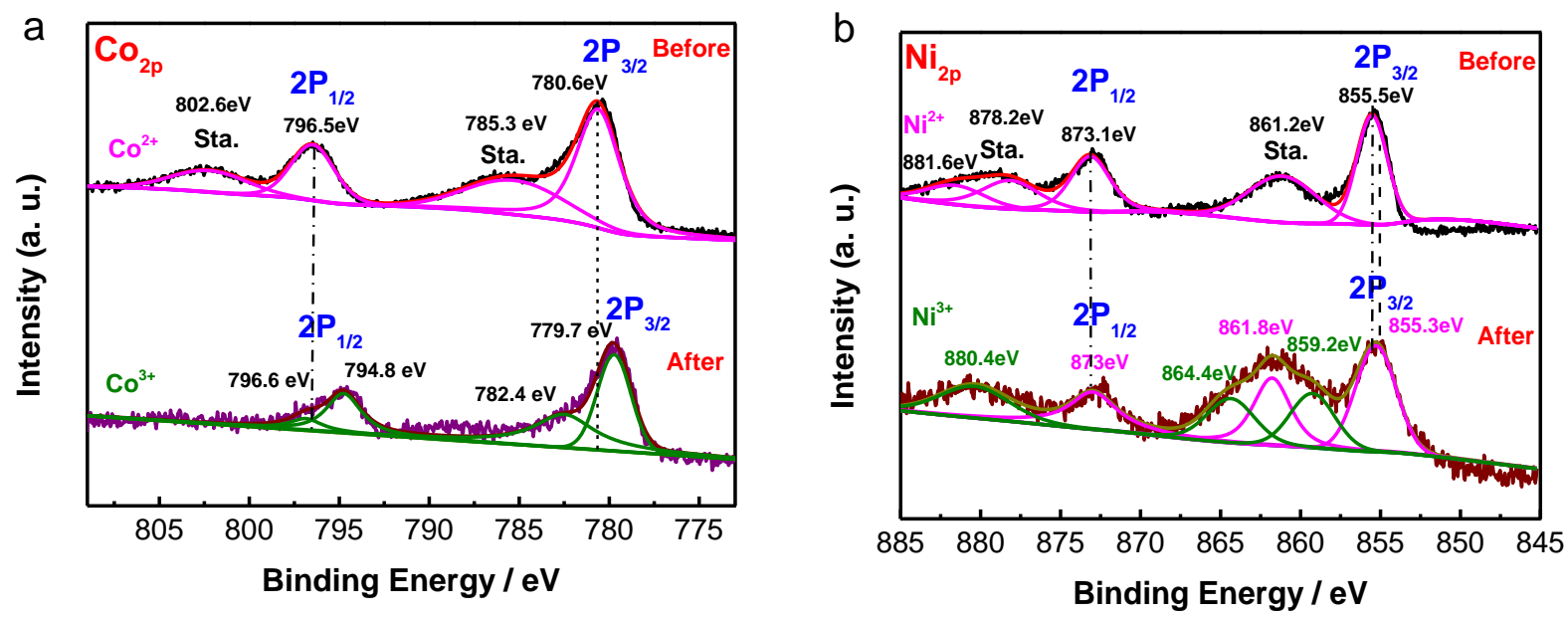

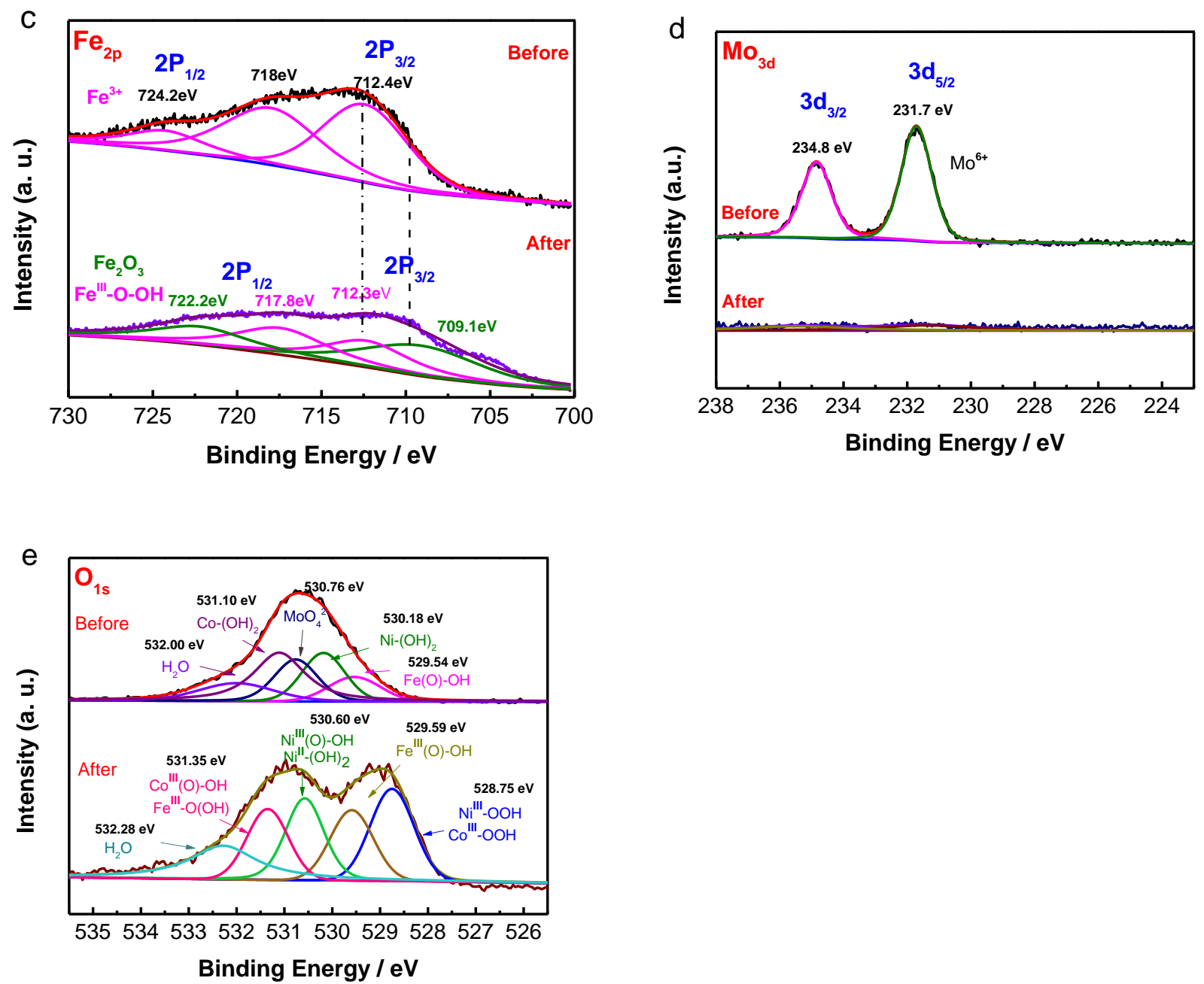

Fig.S11. XPS comparison of the $\mathrm{NiCo}_{1.5} \mathrm{Fe}_{0.5}-\mathrm{LDH} @ 14.7$ at $\% \mathrm{MoO}_{4}{ }^{2-}$ before and after OER processes for (a) Co2p spectrum, (b) Ni2p spectrum, (c) Fe2p spectrum, (d) Mo3d and (e) O1s spectra, respectively.

For the $\mathrm{NiCo}_{1.5} \mathrm{Fe}_{0.5}-\mathrm{LDH} @ 14.7 \mathrm{at} \% \mathrm{MoO}_{4}{ }^{2-}$ sample, the $\mathrm{Co} 2 \mathrm{p}, \mathrm{Ni} 2 \mathrm{p}$ and $\mathrm{Fe} 2 \mathrm{p}$ spectra have the same changes as the $\mathrm{NiCo}_{1.5} \mathrm{Fe}_{0.5}$-LDH sample after OER polarization. Mo3d spectrum contains two spin-orbit splitting Mo3d $\mathrm{d}_{5 / 2}$ and $\mathrm{Mo}_{3 / 2} \mathrm{~d}_{3 / 2}$ at $231.7 \mathrm{eV}$ and $234.8 \mathrm{eV}$ before electrolysis, which are assigned to the characteristic peaks of a $\mathrm{Mo}^{6+}$ oxidation state. After OER, the two characteristic peaks of the $\mathrm{Mo}^{6+}$ almost disappear (Fig.S11d), indicating the $\mathrm{MoO}_{4}{ }^{2-}$ anions in the interlayer have been exchanged by $\mathrm{OH}^{-}$and $\mathrm{H}_{2} \mathrm{O}$. In the high- 
resolution O1s spectra (Fig.S11e), two intense separated peaks at bonding energies of $530.9 \mathrm{eV}$ and $529 \mathrm{eV}$ are also observed after OER polarization, which verifies that trivalent $\mathrm{Co}^{\mathrm{III}}, \mathrm{Ni}^{\mathrm{III}}$ and $\mathrm{Fe}^{\mathrm{III}}$ species are formed on the surface of the $\mathrm{LDH}$ sample with the $\mathrm{MoO}_{4}{ }^{2-}$ anions.
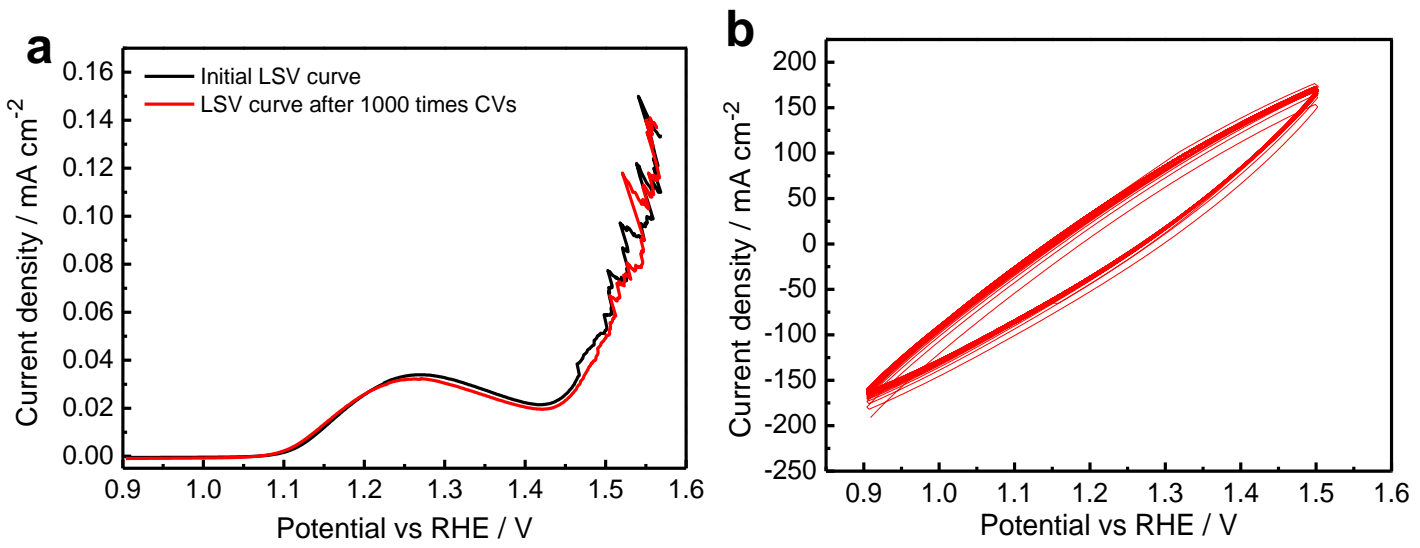

Figure S12. The LSV curves of the $\mathrm{NiCo}_{1.5} \mathrm{Fe}_{0.5} @ 14.7$ at $\% \mathrm{MoO}_{4}{ }^{2-}$ sample (a) before and after $1000 \mathrm{CV}$ cycles were compared to evaluate the stability of its performance and (b) CV curves with 1000 cycles at $100 \mathrm{mV} \mathrm{s}^{-1}$.
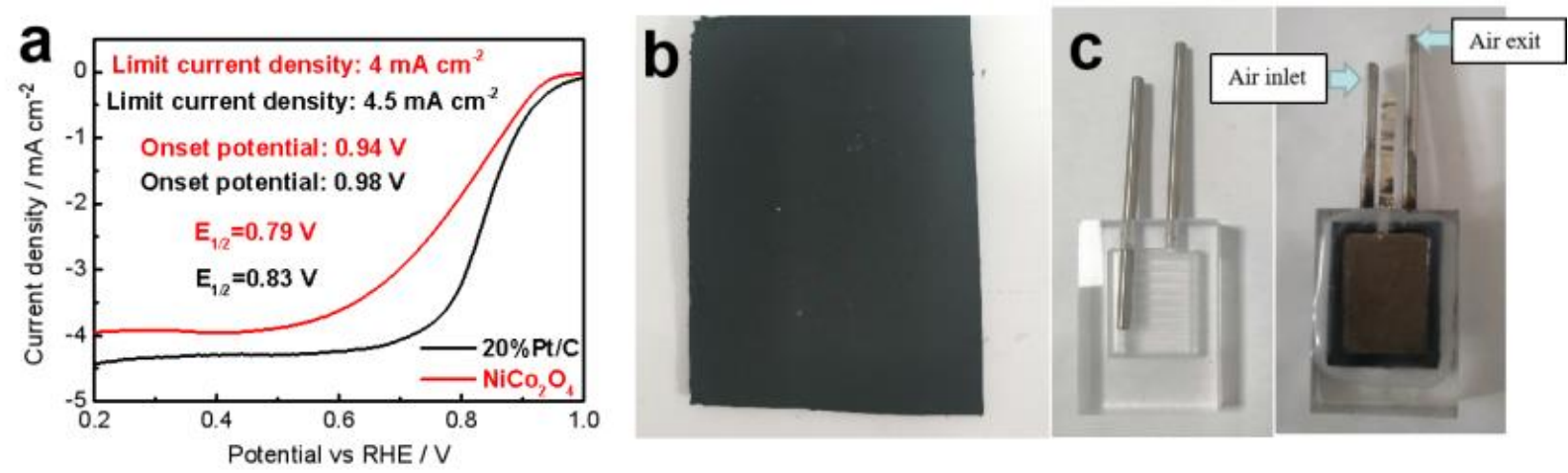

Fig.S13. (a) The $\mathrm{NiCo}_{2} \mathrm{O}_{4}$ and commercial $20 \mathrm{wt} \% \mathrm{Pt} / \mathrm{C}$ ORR catalytic activities were evaluated by the LSV at a rotation speed of $1600 \mathrm{rpm}$ in $\mathrm{O}_{2}$ saturated $0.1 \mathrm{M} \mathrm{KOH}$ solution; (b) the ORR layer; (c) the rechargeable air electrode with an electrode clamp in which an area of $12 \mathrm{~cm}^{2}$ is open for air contact with the air electrode. 
Figure S13a reveals the oxygen reduction reaction LSV curves of $\mathrm{NiCo}_{2} \mathrm{O}_{4}$ and commercial $20 \mathrm{wt} \% \mathrm{Pt} / \mathrm{C}$ electrocatalysts. Compared to the $\mathrm{Pt} / \mathrm{C}$ ORR performance, the $\mathrm{NiCo}_{2} \mathrm{O}_{4}$ also show a low onset potential $(0.94 \mathrm{~V})$, a good limiting diffusion current density $\left(4.0 \mathrm{~mA} \mathrm{~cm}^{-2}\right)$ and half-wave potential $(0.79 \mathrm{~V})$. The physical structure of ORR catalytic layer is shown in Figure $\mathrm{S} 13 \mathrm{~b}$, where the ORR layer is composed of $\mathrm{NiCo}_{2} \mathrm{O}_{4}$ electrocatalysts, Vulcan-72R carbon and Polytetrafluoroethylene.

\section{References}

(1) Schwertmann, U.; Murad, E.; Effect of $\mathrm{pH}$ on the formation of goethite and hematite from ferrihydrite, Clays Clay Miner. 1983, 31, 277-284.

(2) Jambor, J. L.; Dutrizac, J. E.; Occurrence and constitution of natural and synthetic ferrihydrite, a widespread iron oxyhydroxide, Chem. Rev. 1998, 98, 2549-2586. DOI: $10.1021 / \mathrm{cr} 970105 \mathrm{t}$.

(3) Lide, D. R.; Handbook of Chemistry and Physics, 84th Edition, CRC Press LLC, Boca Raton, 2003-2004, pp. 12-154.

(4) Anantharaj, S.; Noda, S.; Appropriate Use of Electrochemical Impedance Spectroscopy in Water Splitting Electrocatalysis, ChemElectroChem, 2020, 7, 2297-2308. (5) Yang, J.; Liu, H.; Martens, W. N.; Frost, R. L.; Synthesis and characterization of cobalt hydroxide, cobalt oxyhydroxide, and cobalt oxide nanodiscs, J. Phys. Chem. C 2010, 114, 111-119.

(6) Zhao, Z.; Wu, H.; He, H.; Xu, X.; Jin, Y.; A high-performance binary Ni-Co hydroxide-based water oxidation electrode with three-dimensional coaxial nanotube array structure, Adv. Funct. Mater. 2014, 24, 4698-4705.

(7) Sankar, S. S.; Ede, S. R.; Anantharaj, S.; Karthick, K.; Sangeetha, K.; Kundu, S.; Electrospun Cobalt-ZIF Micro-Fibers for Efficient Water Oxidation at Unique $\mathrm{pH}$ Conditions, Catal. Sci. Technol. 2019, 9, 1847-1856.

(8) Anantharaj, S.; Venkatesh,M.; Salunke, A.S.; Simha, T.V.S.; Prabu, V.; Kundu, S.; A High-performance Oxygen Evolution Anode from Stainless Steel via Controlled Surface Oxidation and Cr Removal, ACS Sustainable Chem. Eng. 2017, 5, 11, 10072-10083. 